\title{
LEGAL INVESTIGATION OF A MEDICAL INVESTIGATION
}

\author{
MARGARET A. SOMERVILLE*
}

Taking the facts of the case McLean $v$. Weir et al. this paper analyzes in detail the approach of two courts, the British Columbia Supreme Court and the Court of Appeal to what is needed to avoid malpractice in, and obtain 'informed' consent to, diagnostic medical procedure, in this case angiography. The strengths and weaknesses of the various tests for scope of disclosure of information to the patient and for causation, which could be adopted by the law, are discussed. The author concludes by noting some of the problems which are yet to be resolved.

\section{INTRODUCTION}

The role of the doctrine of "informed" consent in regulation of the medical relationship continues to occupy the attention of legislatures and courts in many jurisdictions. McLean v. Weir et al heard at first instance in the British Columbia Supreme Court ${ }^{1}$ and subsequently by the British Columbia Court of Appeal, ${ }^{2}$ offers a framework within which to explore some of the issues raised. The case is particularly interesting in light of the two recent Supreme Court decisions on "informed" consent, Hopp v. $L e p p^{3}$ and Reiblv.Hughes, ${ }^{4}$ as, by way of comparison, it demonstrates the way in which these cases have changed the law and shows some of the problems which are still unresolved.

McLean $v$. Weir et al.: The Facts

The plaintiff was diagnosed by Dr. Weir, a specialist in peripherovascular surgery, as having "progressive Raynaud's phenomenon. In lay terms that means that there was impaired circulation of the forearms hands and fingers." ${ }^{5}$ Dr. Weir referred the plaintiff to Dr. Goff, a radiologist, for angiographic investigation. As a result of a subclavian angiogram performed by $\mathrm{Dr}$. Goff "the plaintiff was rendered permanently and substantially quadriplegic".

The plaintiff initially sued the two doctors and the hospital in which the procedure was carried out on the basis that both Dr. Weir and Dr. Goff had failed to warn him of the "prospective danger of a mishap such as in fact occurred" and that Dr. Goff had negligently carried out the angiogram itself. The Trial Judge held that there was no liability on the part of any defendant and the plaintiff appealed the dismissal of his claims against the two doctors.

\section{MALPRACTICE IN PERFORMING THE PROCEDURE}

The plaintiff did not bring expert evidence to prove malpractice in rela-

* Of the Faculty of Law and the Faculty of Medicine, McGill University, Solicitor of the Supreme Court of New South Wales, Australia.

1. McLean v. Weir, Goff and Royal Inland Hospital [1977] 5 W.W.R. 609, [1977.78] 3 C.C.L.T. 87, Annotation by Ellen Picard Jacobs.

2. McLean v. Weir and Goff, [1980] 4 W.W.R. 330 (B.C. C.A.).

3. [1980] 2 S.C.R. 192, [1980] 4 W.W.R. 645 (S.C.C.).

4. Unreported, October 1980. Coram Laskin C.J.C., and Monkland, Dickson, Beetz, Estey, McIntyre and Chouinard JJ..

5. Supra n. 1 at 611.

6. Id. at 610.

7. Id. 
tion to the claim of negligence in carrying out the angiogram, but tried to rely on the doctrine of res ipsa loquitur as establishing the physician's liability. The Trial Judge was doubtful whether the doctrine applied, ${ }^{8}$ because the cause of the accident was known. However, the Trial Judge held that even if res ipsa loquitur were relevant, the defendant physician had gone further than discharging the requisite onus of giving an explanation of the accident "equally consistent with negligence and no negligence",9 and had shown that there was no negligence on his part. ${ }^{10}$ The Court of Appeal agreed. It concluded that res ipsa loquitur was not available to help the plaintiff prove his case where there was "substantial evidence by way of explanation of how the mishap occurred ..." "i" that is, the cause of the damage was known.

It is true that when the cause of the damage is known it is usually held to be inappropriate to draw inferences against the defendant of either negligence and/or causal responsibility for the damaging act. In short, the doctrine of res ipsa loquitur is inapplicable. Rather, the conduct in question must be examined by the court to see whether it falls below the required standard ${ }^{12}$ and the plaintiff, in general, will no longer need to rely on an inference that the defendant was causally responsible. But there may be good reason to apply the maxim, ${ }^{13}$ or something like it, ${ }^{14}$ in some medical malpractice cases in which the cause of the damage is known. In cases where the defendant is in a much better position to disprove either negligence or his causal responsibility for it, than the plaintiff is to prove either of these factors, ${ }^{15}$ the defendant could be required to bring evidence to show that his conduct is equally as consistent with non-

8. Id. at 617.

9. Id. at 615, citing Duff C.J.C. in United Motors Services Inc. v. Hutson [1937]S.C.R.294, 4 I.L.R. 91. [1937] 1 D.L.R. 737 at 738.

10. Id. at 619.

11. Supra n. 2 at 12.

12. See J.G. Fleming, The Law of Torts (5th ed. 1977, The Law Book Co., Sydney, Australia) at 307-308.

13. See Ybarra v. Spangard, 154 P. 2d 687 (Calif. 1944). In Hobson v. Munkley (1.977) 74 D.L.R. (3d) 408, Krever J., at 417, cites the Supreme Court of Canada's acceptance (in Jackson et al v. Millaret al [1976] 1 S.C.R. 225, 59 D.L.R. (3rd) 246, 4 N.R. 17, per Spence J. at 235-6 S.C.R., 254-5 D.L.R.) of the description of res ipsa loquitur in Clerk \& Lindsell on Torts (13th ed. 1969) at 968 . This description includes a requirement that "there must be no evidence as to why or how the occurrence took place". But Krever J. does not appear to use the fact that how the damage took place in the case before him was known (p. 418) as a reason to reject application of the maxim res ipsa loquitur. Rather, he held the maxim did not apply because the event did not itself bespeak negligence (p. 418). Although it is obiter, this case could certainly be argued as standing for the proposition that res ipsa loquitur may be applied in medical malpractice cases, depending on the circumstances, "(1) when the thing that inflicted the damage was under the sole management and control of the defendant, or of someone for whom he is responsible or whom he has a right to control; and (2) whenever common experience or, lacking such common experience, the evidence in a given case indicates the mere happening of an accident may be considered as evidence that reasonable care has not been used". That is, in order to make use of the maxim, it may not be necessary that the cause of the damage be unknown.

14. For example, a doctrine such as that found in Cook v. Lewis [1951] S.C.R. 830, in which the onus of proving the causal link between the breach of duty and the damage is shifted from the plaintiff and becomes an onus on each defendant to disprove causation. See also the current American cases against the manufacturers of diethylstilboestrol (D.E.S.) (for example Abel v. Eli Lilly \& Co. 48 U.S.L.W.2642 (1980) ) in which the same type of approach has been taken by several courts.

15. See Ybarra v. Spangard, cited supra n. 13. 
negligence as negligence, or even to disprove negligence on the balance of probabilities.

The claim of malpractice in conducting the angiogram also raised some other points which are worth noting. First, both Courts recognized the physician's right to rely "on the general and approved practice [that is, medical custom] defence" against alleged malpractice. ${ }^{16}$ Further, the "state of the art" in to be judged at the time the procedure was carried out. ${ }^{18}$ At that time Dr. Goff was not ${ }^{19}$

... aware of the specific risk of paralysis (nor was this generally known) and Dr. Goff clearly did not, and was not in a position to, alert the patient to this possibility. Had the specific risk of paralysis, such as occurred here, been known to radiologists at that time, ... [the Court of Appeal] would expect the duty of the radiologist would be, not simply to warn the patient of it, but to avoid the very danger itself.

The last part of this statement raises some problems. It may confuse the duty to warn of a risk ${ }^{20}$ with the duty to avoid unreasonable risks. Whether there was a duty to avoid a certain risk in the circumstances of this case, depends firstly on whether a reasonably competent radiologist would have offered the procedure in question to this patient; and secondly, if he would have done so, whether the way in which the defendant carried out the procedure was within the range of options open to a reasonably competent radiologist. The defendant radiologist was in breach of his duty if, considering the seriousness and probability of the risks of harm involved in the procedure itself or in carrying it out in a certain manner, a reasonably competent radiologist would either not have offered the procedure to this patient or would not have carried it out in the way in which it was performed.

The issue of whether or not the angiogram was reasonably indicated in the circumstances was not raised in the case - that is, unless the Court of Appeal's statement, that they did not "agree that this was an elective case ... [in which] the patient ought to be ... given some say whether to undertake the procedure at all"21 is taken as a holding that it was proper to have recommended it.

With respect to establishing the standard against which alleged malpractice in carrying out a procedure is to be judged, the Trial Court held (and the Court of Appeal appears to accept $t^{22}$ ) that the Court "cannot substitute its own medical opinion for that of qualified experts" ${ }^{23}$ Thus where the plaintiff brings no expert medical evidence and there is "unanimous medical evidence", as in this case, such evidence sets the legal standard of care. This may be compared with the American case of Helling v. Carey. ${ }^{24}$ which held that the Court was the final arbiter of whether even accepted medical custom constituted a non-negligent stan-

16. Supra n. 1 at 617; Court of Appeal, supra n. 2 at 338.

17. Supra n. 1 at 616.

18. Supra n. 2 at 334. For a similar observation see Roe v. Minister of Health and Another [1954] 2 Q.B. 66, per Denning L.J. at 84.

19. Supra n. 2 at 337.

20. This aspect of the statement is discussed infra, p. 185 et seq.

21. Supra n. 2 at 337.

22. Id. at 336-338.

23. Supre n. 1 at 620.

24. 519 P. 2d 981 (Wash. 1974). 
dard. The latter is certainly the more traditional tort approach to the "standard-setting" effect of custom in areas other than that of medical practice. ${ }^{25}$ The difference is between directly accepting the standards of the medical profession as the legal standards, and accepting these standards as evidence on which the court will determine the relevant legal standards.

In the result, both Courts found no negligence by the defendant physician in carrying out the investigation.

\section{CONSENT}

The other matter dealt with was the duty of the defendant physicians to warn their patient of the risks of the procedure in order to obtain his informed consent to it.

\section{A. Who Should Inform?}

It was held that Dr. Weir, the referring physician, followed "an eminently sensible course of conduct"26 in leaving the informing to the doctor who was actually going to carry out the procedure. It is true that such an approach was justified on the facts of this case, where another specialist, more knowledgeable with respect to the proposed procedure than the referring specialist, was to undertake it. But there would be a danger in extending this reasoning to cover the other common case of performance of medical treatment by an alternative doctor, that which involves delegation to a more junior colleague. In such instances it can be assumed that the directly treating doctor knows less than his referorsuperior. Accordingly, it is suggested that the duties of the senior professional, which include the duty to inform the patient and obtain his consent, should be non-delegable, at least with respect to liability for their non-performance, if not in regard to actually carrying them out. ${ }^{27}$

Further, it should be considered whether referral to another doctor is part of the treatment undertaken by the first physician. ${ }^{28}$ If so, the risks involved in such referral should be disclosed to the patient. The standard of such disclosure need only be very general. Perhaps here, for example, the referring doctor should have warned the patient to the effect that "if an investigative procedure is recommended (which is clearly contemplated as a strong possibility in referring a patient to a radiologist) there could be some risks involved and you should ask $\mathrm{Dr} X$ about these".

B. Content of the Duty to Inform

What should the doctor have told the patient in the circumstances presented in $M c L$ ean v. Weir? The problems faced in answering this question are displayed in the expert medical evidence which is extensively referred to in the judgment at first instance.

25. See Cavanagh v. Ulster Weaving Co. Ltd. [1960] A.C. 145.

26. Supra n. 1 at 612; Court of Appeal, supra n. 2 at 332.

27. The concept of non-delegable duties hinges on separating the obligation to perform from the obligation to compensate for wrongful performance. Then one argues that either of these obligations may be non-delegable. For instance, the former (which, of necessity, includes the latter) will be non-delegable when there is a contract of personal service. However, in some situations performance may be validly delegated, but not liability to compensate for wrongful performance. In such cases the latter obligation (and only the latter obligation) is non-delegable.

28. See Picard Jacobs, supra n. 1 at 90 , who raises the same point. 


\section{1. "Therapeutic Privilege"}

First the "dilemma between telling the patient enough so that he can give ... an informed consent and not telling him so much that he will become anxious and apprehensive and so nervous that he might be reluctant ... to go forward with a procedure that is necessary"29 is raised. This is the issue of "therapeutic privilege"; that is, the doctor's privilege in certain circumstances (reliance on which he must justify) to make less than the full disclosure of information which the law would normally require. ${ }^{30}$

However, the above formulation of this doctrine may be too broad. The approach suggested is that the doctor should be able to rely on "therapeutic privilege" to justify a non-disclosure of risks where a reasonable doctor would have believed that such disclosure in itself would physically or mentally harm the patient. The doctrine should not apply where the only reason for the non-disclosure is that it may have the result of causing the patient to refuse treatment which the doctor regards as necessary. ${ }^{31}$ To refuse such treatment after being properly informed of its risks and benefits and those of its rejection is the patient's right.

The suggested approach does not appear to be inconsistent with recent statements by the Supreme Court of Canada. In Hopp v.Lepp, the Court had the following to say about the scope of the doctrine of "therapeutic privilege": ${ }^{32}$

No doubt, a surgeon has some leeway in assessing the emotional condition of the patient and how the prospect of an operation weighs upon him; the apprehension, if any, of the patient, which may require placating; his reluctance, if any, to submit to an operation which, if the surgeon honestly believes that the operation is necessary for the preservation of the patient's life or health, may demand a detailed explanation of why it is necessary.

\section{But, Chief Justice Laskin, speaking for the Court, was: ${ }^{32 a}$}

... far from persuaded that the surgeon should decide on his own not to warn of the probable risk ... if the course of treatment contemplated is administered. A surgeon is better advised to give the warning, which may be coupled with a warning of the likely consequence if the treatment is rejected. The patient may wish for a second opinion, whatever be the eminence of his attending physician. It should not be for that physician to decide that the patient will be unable to make a choice and, in consequence, not to warn him of risks.

\section{Likewise in Reibl v. Hughes, the Supreme Court acknowledged that: $:^{33}$}

... it may be the case that a particular patient may, because of emotional factors, be unable to cope with facts relevant to recommended surgery or treatment and the doctor may, in such a case, be justified in withholding or generalizing information as to which he would otherwise be required to be more specific.

However, the Court held that the normal disclosure requirements were

29. Supra n. 1 at 621.

30. It should be noted that there may be a danger in a court dealing with 'therapeutic privilege' before the normal scope of disclosure required in the particular circumstances of the case is determined. Although such an approach is understandable in that the privilege affects the final scope of disclosure required by the law, the danger is that therapeutic privilege may not be recognized as the exception that it is to the normal rule, and hence may not be construed as narrowly as it should be.

31. In fact, it has been shown that more complete information rarely leads to a refusal to go through with a procedure (A.I. Fadden and R. R. Fadden, "Informed consent in medical practice with particular reference to neurology", Arch. Neurol, 1978; 35: 761-4). Further, as D. Rennie says ("Informed Consent by Well-Nigh Abject Adults", N. Engh J. Med. 1980, 302: 917-8) "one might question whether withholding information really increases mutual trust".

32. Hopp v. Lepp, cited supra n. 3 at 655-656.

32a. Id. at 658.

33. Reibl v. Hughes, supra n. 4 at 13. 
not modified as "there was no evidence that the plaintiff was emotionally taut or unable to accept disclosure of the grave risk to which he would be exposed by submitting to surgery".".4

Thus, while recognizing "therapeutic privilege", the Supreme Court seems to have taken a reasonably restrictive approach to its application. The physician may be required to disclose to the patient and then "placate" and "explain" to avoid adverse effects of the disclosure, rather than avoiding the dialogue which will cause anxiety in the patient (and, possibly, the physician). There is a suggestion that "therapeutic privilege" may only operate when someone else, presumably another physician, agrees that its application is warranted. Moreover, it would seem that before the privilege will apply, account must be taken of whether any adverse effects of disclosing the risks of the proposed procedure to the patient can be offset by disclosing to him the risks of not having the procedure. Despite the somewhat mandatory language used by the Supreme Court in this regard, if such a "set-off" seems unlikely to occur with respect to a particular patient, or if disclosing the risks of not having treatment could additionally harm the patient's physical or mental health, then, presumably, "therapeutic privilege" would apply. Finally, the Supreme Court indicated that the privilege is not always complete; that is, when the patient can cope with the information in a more generalized form this must be given, and in such cases total nondisclosure will not be justified.

Any reliance on the doctrine of therapeutic privilege should be distinguished from an entirely different justification for non-disclosure referred to by an expert witness in McLean v. Weir: that certain "complications are known to have occurred, but they are rare and we do not tell the patient those things are possible because we do not expect them to happen"..$^{34 a}$ This distinction between a non-disclosure justified by "therapeutic privilege" and that justified on the basis of low probability of the risk occurring, is not clearly drawn in the expert evidence cited in the trial judgment in the case. Further, the Court of Appeal may have continued this confusion by approving Dr. Goff's explanation, which "avoided rare and unexpected complications which would serve only to make the patient anxious and apprehensive". ${ }^{35}$ Moreover, although it is most unlikely to have been intended, this statement of the Court of Appeal could be interpreted as formulating a justification for non-disclosure which requires cumulative, rather than alternative, criteria. That is, nondisclosure of certain risks would only be justified if they were both "rare and unexpected" and would "make the patient anxious and apprehensive".

A justification of non-disclosure based on the rarity of the risk is coherent with modern doctrine regarding the scope of disclosure required for "informed" consent, provided that any such justification is carefully restricted to genuinely improbable risks (taking into account that the degree of probability requiring disclosure will vary inversely with the seriousness of the risk). In contrast, to allow justification of a

34. Id at 42.

34a. Supra n. 1 at 622.

35. Supra n. 2 at 336. 
non-disclosure simply on the basis of avoiding making the patient anxious and apprehensive, or to prevent him refusing the proposed intervention, would contravene the requirements of this doctrine.

2. Scope of Disclosure

In Canada, as McLean v. Weir demonstrates, the scope of the duty to disclose used to be determined by expert evidence of what constituted accepted medical practice with respect to disclosure of a particular risk: $:^{36}$ the so-called "professional disclosure" standard. The alternative approach, adopted in some jurisdictions of the United States, is that the scope of disclosure is determined according to what the reasonable patient in those circumstances would want to know: ${ }^{37}$ the "full disclosure" standard. On the whole, this latter approach had been rejected by Canadian courts, except in relation to non-therapeutic medical interventions. ${ }^{38}$ However, the Supreme Court of Canada has now held that the "full disclosure" standard is the one generally applicable under Canadian law ${ }^{3{ }^{8 a}}$ Further, the Supreme Court has ruled that expert medical evidence does not, of itself, set even the medical content of the required standard of disclosure. Rather, it is for the court to set the standard, and in the case of medical risks, this will be done on the basis of expert medical evidence ${ }^{39}$ This latter ruling also contrasts with those in McLean v. Weir, in which both the Trial Court and the Court of Appeal displayed a strong tendency to accept the expert medical evidence as, in itself, directly setting the required legal standard of disclosure.

However, despite the fact that the "professional disclosure" standard is no longer the law, cases such as McLean v. Weir which were based on that standard, are still relevant. This is true because, as the Supreme Court recognizes, ${ }^{40}$ the broader "reasonable patient" or "full disclosure" standard which now applies necessarily includes, but is not limited to, the "professional" standard. Consequently, these cases demonstrate some of the problems which exist in determining "(1)[the] risks inherent in a given procedure or treatment, (2) the consequences of leaving the ailment untreated, (3) alternative means of treatment and their risks, and (4) the cause of the injury suffered by the plaintiff-patient". ${ }^{403}$ Further, although the expert evidence referred to in McLean v. Weir may be a somewhat extreme example, this case provides a good demonstration of why the Supreme Court retained the ultimate discretion in the court to determine the required scope of disclosure, including disclosure with respect to purely medical risks. Before analyzing that evidence, however, certain similarities between the "professional" and "full" disclosure standards should be noted.

Under either approach the scope of the required disclosure will be ex-

36. Kelly v. Hazlett (1977) 75 D.L.C. (3d) 536 at 565; Lepp v. Hopp (1979) 8 C.C.L.T.260(Alta. C.A.) (Annotation by E. Jacobs Picard).

37. See, for example, Canterb'.ry v. Spence, 464 F. $2 d 772$ (1972).

38. See Halushka v. Univer, ity of Saskatchewan (1965) 52 W.W.R. 608, 53 D.L.R. (2d) 436 (Sask. C.A.).

38a. Hopp v. Lepp, supra n. 3.

39. See Reibl v. Hughes, supra n. 4 at 10.

40. Id at 13-14.

40a. Id. at 14, quoting Comment, "New Trends in Informed Consent" (1975) 54 Neb. L. Rev. 66 at 90 . 
tended to include information which the physician knows or ought to know the particular patient wants; for instance, because the patient has asked a question. ${ }^{11}$ Moreover, under both standards the objective factors most affecting the decision as to whether or not a particular risk is required to be disclosed will be the probability of any given risk occurring, and its seriousness should it eventuate.

In McLean v. Weir, the first step in determining what medical risks should have been disclosed was to establish what constituted good medical practice on disclosure of risks by radiologists when carrying out angiograms at the time the procedure was performed on the plaintiff. The expert witness' initial statement to this effect was as follows: "Well, we have gone both ways on this issue of informed consent. Initially we would go into great detail and explain to the patients all possible risks ... [But] we now have a standard policy ... and do not tell them what the risks are." $\$ 2$ This is certainly understandable from the doctor's point of view; it can be an uncomfortable, emotionally disquieting and time-consuming task to explain risks of treatment to patients. But the point again, as it was in deciding on the width of operation of the doctrine of "therapeutic privilege", is: whose preference as to disclosure, and hence whose decision as to whether to take the risks and undergo the treatment, should be determinative - the doctor's or the patient's? This witness continued that sometimes he would tell the patient "in detail how the study will be done ... and what we hope to accomplish". ${ }^{43}$ This is to disclose methods, not risks, and even more significantly, benefits rather than risks, so that the patient is possibly more prejudiced in reaching a balanced decision than if he were left in total ignorance.

More particularly, in relation to the choice of words used in the disclosure, this expert medical witness said he did "not use the word 'dye' because it is not a dye - rather [he] employs the more accurate term 'contrast agent' to describe what will be injected into the patient's artery". 4 While this is true, it is also a fact that euphemisms are often used in order to avoid alarming patients or even making them sufficiently aware to ask unwanted questions. ${ }^{45}$

Patients were also told there would be "moments of discomfort", but were reassured that "there are any where between two to six types of this examination done per day ... in our hospital". ${ }^{46}$ The witness continued that "I tell... [patients that] when they come in we will explain everything to them as we go along, and ... I say, 'If you have any questions, ask'. I give them the possibility of asking about complications." ${ }^{\prime \prime}$

The evidence referred to in the preceding paragraph raises several problems in relation to informed consent. First, physicians explaining to a patient as they "go along" are not informing him in a non-coercive atmosphere. This could mean that coercion is present to such an extent that

41. See, for instance, Hopp v. Lepp, cited supra n. 3, and the discussion in note 51, infra

42. Supra n. 1 at 622.

43. Id.

44. Id.

45. See B.H. Gray, Human Subjects in Medical Experimentation (1974, John Wiley \& Sons, New York) at 118.

46. Supra n. 1 at 622.

47. Id. 
the consent is totally defective. Secondly, if informed consent requires not only informing, but also understanding, carrying out the informing in such a situation will, at the least, inhibit understanding. Thirdly, even if the patient is informed and understands, it may be too late for him to withdraw from the proposed treatment, or it may be more dangerous for him to do so than to go forward with it. Fourthly, it is not clear what scope of disclosure is contemplated by explaining "everything". The preceding statement, that an explanation is given of "how the study will be done", may only cover the steps of the technical methodology and omit disclosure of the risks involved in such techniques. ${ }^{49}$

Lastly, a major problem which this statement reveals is the belief that the duty to disclose only arises on the patient's demand. It is now clear that this is not the law. ${ }^{50}$ It is for the physician to obtain consent for purposes of the torts of battery and negligence: in the former case because the physician is the intervenor, and in the latter because the physician has a duty to inform the patient and to obtain his consent prior to an intervention. As there is this burden on the physician, and no onus on the patient to give consent, consent cannot be implied when there is no disclosure, although the patient had a chance to ask questions. ${ }^{51}$ Rather, the inference in such circumstances will be that there was no consent. ${ }^{52}$

To determine the minimum required scope of disclosure of information according to the questions asked by the patient is the least exacting standard of disclosure that could be used. To the contrary, the law now is that, rather than having such a limiting effect on the required scope of disclosure, a patient's questions will operate to extend that scope. Moreover, such questions may have another function. The Court of Appeal of Ontario, in Reiblv. Hughes, ${ }^{53}$ proposed that a patient has a duty to tell the doctor if he does not understand the information he has been

48. Id.

49. For reference to disclosure actually made by Dr. Goff to the plaintiff, see id. at 620-621 and infra at p. 180.

50. See Hopp v. Lepp, supra n. 3, and Reibl v. Hughes, supra n. 4.

51. It should be noted that there is a difference between rejecting that the required minimum standard of disclosure be set according to the questions asked by the patient, and allowing the minimum standard otherwise required to be made more exacting by the particular patient's questions. Such rejection and allowance, respectively, will be adopted to determine the required scope of disclosure of information in any given case. See Hopp v. Lepp, cited supra n. 3.

52. It could be that if an approach were adopted of limiting the scope of disclosure to answering questions asked by the patient, the patient could give consent although he asked no questions. For instance, this would be so if the patient's acquiescence in treatment constituted sufficient consent to avoid an action in battery. (See, for example, O'Brien v. Cunard S.S. Co. 154 Mass.272,28 N.E.266(1891).) The patient's consent will be sufficient to negate battery, if one can presume that he understood the "basic nature and character of the operation performed" and then subsequently underwent the procedure. Such a presumption is theoretically possible where the facts needing to be disclosed to avoid a cause of action in battery are matters of common knowledge. It is much less likely that such a presumption would be available to assist a doctor in a negligence action. This is so for two reasons. First the content of the required disclosure is very likely to be a matter of medical, and not common, knowledge. Secondly, if, in order to fulfill the duty required of him as a reasonable doctor within the tort of negligence, the doctor has a duty to disclose certain information (as compared with an obligation to obtain consent which may be his obligation in battery) this duty will not have been honoured by waiting for questions.

53. Reibl v. Hughes (1979) 6 C.C.L.T. 227 at 237 (Ont. C.A.). 
given. ${ }^{54}$ But if placing this obligation to enquire on the patient means that the physician does not have a duty to take reasonable steps to ensure that the patient understands the information he is given, such an obligation to enquire would also be undesirable. It may also overlook the power and status differential in the doctor-patient relationship. From a practical point of view, such a power imbalance makes the patient less likely to ask questions or to understand what he is told, and also makes him reluctant to disclose this to the doctor. Further, the patient may not even know enough to ask appropriate questions, or to know he does not understand the answers, or he may be too emotionally upset to realize this. To set the required scope of disclosure according to the patient's questions is to place a somewhat unrealistic and unreasonable obligation on the patient, with the result that the physician could be relieved of liability even though he had made no effort to inform the patient.

A further point is that even if it were true that the scope of the physician's duty of disclosure were to be determined by the patient's questions, the situation is different in cases such as McLean v. Weir. It was not a case of total non-disclosure or of only answering questions asked by the patient, but rather of disclosure only of those facts considered appropriate by the doctor. In such circumstances one may have a situation of halftruth, which is quite different legally and ethically from a situation of no disclosure at all, or even a situation where it is accepted that the patient sets the limits to disclosure by his questions. A duty to inform adequately may be assumed in the "half-truth" situation where, in the other circumstances referred to, no such duty may exist.

In this respect, the Court of Appeal's comments in McLean v. Weir regarding the plaintiff's claim in battery, on the basis of "[u]ninformed" consent, are interesting. Carrothers J.A., speaking for the Court, held that: $:^{35}$

... this case lacks an actual misdescription or misrepresentation of the nature or effect of the radiological procedure, such as was found to be a necessary element to negative the patient's consent in Haluska v. The University of Saskatchewan et al (1965) 53 D.L.R. (2d) 436; see also Koehler v. Cook (1975) 65 D.L.R. (3d) 766. In my view, the appellant was adequately informed and he effectively had consented to the procedure. I cannot find battery or assault in this case.

To appreciate the real significance of this statement, it is necessary to recall what the plaintiff was told by the defendant physician. He was given "an outline of the somewhat complicated mechanics of the procedure" and a warning that he was "quite likely to get a bruise in the groin with blood leaking out from the artery past the catheter" ${ }^{56}$ The only other "hazard" disclosed to the plaintiff was the risk of developing a blood clot, blocking an artery to his leg, which would require surgical removal of the clot. ${ }^{57}$ Thus the Court of Appeal found that the non-disclosure of the known risk of paralysis was not a misdescription or misrepresentation sufficient to vitiate the patient's consent as far as battery was concerned. This raises the often debated question of when a non-disclosure can amount to a misdescription or a misrepresentation. Clearly, it can where a partial disclosure has been made and not to disclose fully would be

54. Id at 237 .

55. Supra n. 2 at 336.

56. Supra n. 1 at 620-621.

57. Id. 
misleading or where there is a duty to disclose, which is either assumed or imposed by law. However, in the absence of either a partial misleading disclosure or a positive duty to disclose, misdescription and misrepresentation normally require malfeasance and not merely nonfeasance. Here then, the Court must have found that there was neither breach of a duty to disclose, nor a misleading partial disclosure as to the nature or effect of the procedure.

It is worth asking why the Court of Appeal formulated the scope of disclosure test relative to battery-avoiding consent in terms of misdescription and misrepresentation. The Court, in effect, said that there will only be liability in battery on the basis of non-disclosure for failure to disclose those risks which, if not disclosed, would cause the procedure to be misdescribed or misrepresented. Thus the Court adopted an approach which envisaged situations where, despite a duty of disclosure having been breached, there would be no liability, at least in battery, as the breach did not constitute a misrepresentation or misdescription to the patient of, presumably, the basic nature and character of the procedure. Some of these non-disclosures which would not give rise to a cause of action in battery may sound in negligence. Thus, the "misdescription or misrepresentation of the procedure" test was not used as a means of determining the full scope of the duty to disclose, but as a means of marking off which breaches of a duty to disclose would sound in battery and which in negligence. ${ }^{58}$

This approach should be compared with that of the Supreme Court in Reibl v.Hughes. Essentially, the Supreme Court held that non-disclosure of a risk cannot give rise to a cause of action in battery. In other words, the Supreme Court seems to reject the proposition that non-disclosure of a risk, no matter how material, could ever amount to a misrepresentation of the basic nature and character of the operation..$^{59}$ Rather: ${ }^{59}$

... actions of battery in respect of surgical or other medical treatment should be confined to cases where surgery or treatment has been performed or given to which there has been no consent at all or where, emergency situations aside, surgery or treatment has been performed or given beyond that to which there was consent ... [U]nless there has been misrepresentation or fraud to secure consent to the treatment, a failure to disclose the attendant risks, however serious, should go to negligence rather than to battery.

Thus, the question still arises as to what constitutes a misrepresentation; but it would seem that non-disclosure of a risk usually does not. ${ }^{59}$

Further expert evidence given in McLean v. Weir of the practice of radiologists in disclosing the risks of angiography to patients is also of interest. One witness testified: ${ }^{30}$

I tell them of no pain or risk factors unless ... a patient specifically asks or indicates to me in some way, and usually a non-verbal way, he wants to know those risk factors .... The second group I would tell are those patients that have a very, very high risk, those I will or will tell the relatives of that patient.

58. See Kelly v. Hazlett, supra n. 36; Reibl v. Hughes, supra n. 53, especially at p. 245 . For a discussion of how the full scope of the total duty to disclose will be determined, see supra p. 177 et seq.

59. Reibl v. Hughes, supra n. 4 at 7-10.

59a. Id. at 9-10.

59b. For further discussion of the implications of this holding of the Supreme Court, see M.A. Somerville, "Structuring the Issues in 'Informed' Consent" (1981) 26 McGill L.J. (4) (forthcoming).

60. Supran. 1 at 623. 
It is clearly the right of high-risk patients to be informed in order to allow them to choose for themselves whether to run the risk of treatment, or the risk of refusing treatment. The problem is the restricted class in respect to which this approach is employed, although the "good faith" reasons behind this limitation are not doubted. The further difficulty is the assumption that it serves equally as well to disclose risks to the relatives as to the patient. Legally this is an invalid assumption, unless perhaps the justification of "therapeutic privilege" is properly applicable. In such a case the physician is justified in not disclosing to the patient and it is arguable that he should, ethically, obtain the consent of those most likely to have the patient's best interests at heart and to know the decision the patient would make if he could be asked without harming him.

The radiologist then gave evidence that there had been complaints about him from patients and attending staff to the effect that he "was scaring patients needlessly ... [by] going into too much detail"..$^{00}$ Despite this he felt it necessary to obtain an informed consent when he conducted "a special mylographic trial with a new agent" (a medical experiment). He gave evidence that obtaining informed consent entails explaining "to the patient the possible differences between this agent and the old agent, and also how the examination will be done ..." ${ }^{62}$ This, he said, "takes half an hour of my time, and I may do this twice or three times a day, and at the end ... the patients ... say -95 percent of them will say - 'What would you do?" ". ${ }^{\theta 3}$ In other words, "[t]hey don't want to hear this - they want me to tell them what they should do, without taking half an hour... . The majority of patients don't want to hear it and they can't understand what you are trying to tell them." ${ }^{\circ 4}$

There are several comments to be made about this evidence. First, there is no doubt that a full disclosure of risks must always be made before undertaking medical experimentation, ${ }^{65}$ even when it is therapeutic, and especially when an alternative therapy is available. There is again, however, no indication that any risks, apart from the additional ones involved in using the new agent as compared with the old, were disclosed. Secondly, the problem of time pressure on the doctor is raised. Is one justified in asking a doctor to spend half an hour of his time explaining to a patient? In this respect, can the practical realities of medicine be reconciled with the theoretical requirements of the law on informed consent? Thirdly, the patient's question, "What would you do?" is interpreted by a non-sequitur. That is, it is construed as meaning, "I, the patient, want you, the doctor, to decide for me". Rather, it is suggested that the patient is asking the doctor, as an expert, for advice. This advice the patient will take into account in reaching his own decision, which will be based on many more factors than simply what his advisor would do if he were faced

60a. Id. This evidence should be compared with the finding of R.J. Alfidi, "Informed Consent: A Study of Patient Reaction".J.A.M.A. 1971; 216: 1325-9, who found that "straightforward and perhaps even harsh statements" concerning possible complications of angiography were "accepted and desired by patients".

61. Id.

62. Id. at 623-624.

63. Id at 624 .

64. Id.

65. Halushka v. University of Saskatchewan, cited supra n. 38 . 
with the same decision..$^{66}$ Fourthly, there is the statement that patients do not want to hear the information and, even if they do, they do not understand it. A patient may always waive the right to be informed of risks in the purely therapeutic situation. But in the context in which this statement is made, that of medical experimentation, the presence of such factors should constitute a bar to the experimentation. In other words, except possibly in rare instances when a very stringently applied doctrine of "therapeutic privilege" may apply, the patient should be given the normal therapeutic regime in such circumstances. This evidence could be read as suggesting, to the contrary, that the patient's implied waiver and non-comprehension of information constitute a "carte blanche" for the research physician.

In the circumstances of this case, according to the expert evidence, the risk to the plaintiff of a serious complication was about one per cent. ${ }^{67}$ In assessing whether he should disclose such a risk, the expert witness said: $:^{88}$

I look at ... [the patients] as a group and say to myself. 'Am I going to go out and scare the hell out of 100 patients so that one patient who may have complications knows about that beforehand'? We have come to this conclusion. No, we will not do this because we are treating them as a group, not as a select individual and it's best if you treat them as a group, you don't scare them....

Apart from completely missing the point as to why disclosure is required - that is, to enable the patient to make his choice of what risks he will run - this statement may be criticized from two perspectives. First, it assumes that one can compare and weigh the risk of scaring one hundred people (although they may not all be scared and, further, there is always a possibility of justified non-disclosure under the doctrine of "therapeutic privilege") against the fact of allowing someone to run a substantial risk of serious injury, in this case becoming quadriplegic, without the knowledge that he was running this risk. Secondly, it is completely unacceptable that any doctor, in any circumstances, for any purpose, treat any person as just one unit of an impersonal group and, to quote, "not as a select individual". Apart from being quite contrary to every code of medical ethics, this completely contravenes the most fundamental of a physician's duties: that of personal care. ${ }^{69}$

\section{The Courts' Holdings on Consent}

Because the judgments of the Trial Court and the Court of Appeal in $M c L e a n \mathrm{v}$. Weir each raise different and important issues with respect to consent, they will be dealt with separately.

\section{The Trial Court's Judgment}

First, it should be noted that the Trial Judge, Gould J., dealt with the totality of the plaintiff's claims simply as "a medical malpractice action" ${ }^{70}$ In particular, with respect to the claims arising from failure to obtain

66. The validity of such an approach and the function of 'informed' consent to aid the patient to make his own decision were recognized by the Supreme Court in Reibl v. Hughes, supra n. 4.

67. Supra n. 1 at 625 .

68. Id.

69. For an excellent development of the theory of this "duty of personal care", see C. Fried, Medical Experimentation: Personal Integrity and Social Policy (1974, North Holland Publishing Co., Amsterdam, Oxford), especially at p. 69.

70. Supra n. 1 at 610. 
legally adequate consent, he made no distinction in his judgment between the legal principles which would apply to a claim in battery, and those applicable to negligence. However, it seems that his reasoning relates to a claim based in negligence. ${ }^{11}$ In contrast, the Court of Appeal dealt separately with the "failure to inform" claims in battery and negligence. ${ }^{72}$

As stated earlier, evidence was given that the risk of serious complications run by the plaintiff was about one per cent. ${ }^{73}$ But, by eliminating those complications which were reversible, the Trial Court characterized the probability of the risk which eventuated as "one in a thousand". "The issue was then defined as: "does the surgeon, before embarking on a procedure of elective surgery, have to warn the patient of all the horrendous 'one in a thousand' possibilities appurtenant to the procedure"? ${ }^{75}$

In answering this question Gould J. first dealt with Halushka v. University of Saskatchewan ${ }^{76}$ which clearly describes the law as requiring a full disclosure of risks to a patient. He distinguished that case on the basis that there "[t]he doctors knowingly deceived [the patient], before the anaesthesia, as to its nature". ${ }^{77}$ One can query whether in fact the court in that case found deceit, which is a difficult and serious element to establish against a professional person. Rather, with respect, they appear to have based their decision on a simple failure to obtain consent, ${ }^{78}$ and negligent non-disclosure of risks, ${ }^{79}$ two entities quite different from the former one.

Two other cases, Koehler v. Cook $k^{80}$ and Beausoleil v. La Communauté des Soeurs de la Charité de la Providence, ${ }^{81}$ were also distinguished. ${ }^{82}$ The basis for this in the former case was that the doctor had expressly reassured the patient that "if lasting complications of importance occurred ... it would be a first time", when, in fact, the possibility of such complications was already known. The latter case was held inapplicable because the undisclosed risk resulted from a procedure which the patient had specifically stated she did not want to undergo.

Gould J. then relied on Kenny v. Lockwood ${ }^{8 s}$ as stating the law: ${ }^{84}$

... the duty cast upon the surgeon was to deal honestly with the patient as to the necessity, character and importance of the operation and its probable consequences and whether success might reasonably be expected to ameliorate or remove the trouble, but ... such duty does not extend to warning the patient of the dangers incident to, or possible in, any operation, nor to details calculated to frighten or distress the patient.

71. See E. Picard Jacobs, supra n. 1 at 89.

72. See supra pp. 180-181, infra pp. $187-188$ et seq.

73. Supra n. 1 at 625.

74. Id at 626 .

75. Id.

76. Cited supra n. 38.

77. Supra n. 1 at 626.

78. Halushka v. University of Saskatchewan, supra n. 58 at 445.

79. Id. at 444 .

80. [1976] W.W.D. 71, 65 D.L.R. (3d) 766.

81. (1964) 53 D.L.R. (2d) 65 (Que. C.A.).

82. Supra n. 1 at 626.

83. [1932] O.R. 141, [1932] 1 D.L.R. 507 (C.A.).

84. Supra n. 1 at 626. 
This case was decided in 1932 and hence represents a legal interpretation of a very different reality with respect to the doctor-patient relationship than that which exists today.$^{85}$ Further, it pre-dates the development of the law of "informed" consent with its duty to disclose founded in negligence. Rather, Kenny v. Lockwood was decided on the basis of the duties arising in a fiduciary relationship of which the doctor-patient encounter is one example. Despite this, apart from the wide definition of "therapeutic privilege" in the above passage, if one extends the word "probable" to include possible although not highly remote consequences, it fairly accurately states the current law.

Without commenting directly on this quote from Kenny v. Lockwood, the Trial Judge appears to have adopted it, together with two other principles which represent an extension of any rule derived from Kenny v. Lockwood. First, he justified allowing physicians alone to set the required standard for disclosure of information to a patient on the basis that "[t]he less the courts try to tell doctors how to practise medicine, the better". ${ }^{88}$ Then he differentiated "communication" from "mere communication": "Insofar as the communication goes beyond mere communication and touches directly upon health and treatment, the communication is part of the therapy of medicine" [emphasis added] ${ }^{87}$ The latter situation includes not only obvious examples such as psychotherapy but also, it seems, cases where the "communication to [the] patient ... undoubtedly would frighten him to the extent either that his treatment would suffer or he would refuse treatment altogether" ${ }^{88}$ Thus the Trial Judge may be including within the concept of communications amounting to "therapy", situations which, if they are to be considered as exceptional at all in relation to the duty to inform, constitute such an exception under the doctrine of therapeutic privilege. Leaving aside any argument as to whether or not Mr. Justice Gould's statement accurately represents the law on therapeutic privilege, to the extent that this statement was meant to apply to the case before the Court, there was a gap in the proof. There was no evidence ${ }^{89}$ apart from inferences or presumptions, that the reasonable patient or this particular plaintiff (the latter of whom it is suggested sets the relevant standard for disclosure in regard to "therapeutic privilege") would have been so frightened. Further, as the burden of proof of such a justification for non-disclosure is on the doctor, in the absence of evidence the justification would be inapplicable. Moreover, the reasoning that the patient would refuse treatment if he were told of the risks is no justification for non-disclosure..$^{90}$

The judgment at first instance then proceeds to state that this "communication-as-therapy" approach means, in relation to the scope of a doctor's duty of disclosure, that "barring negligence in word or economy of truth, the bona fide opinion of a competent practitioner as to what his patient should be told should carry respect of the court to the degree of a

85. See B. Barber, "Compassion in Medicine: Towards New Definitions and New Institu. tions", New EngL J. Med. 1976, 295:939.

86. Supra n. 1 at 609.

87. Id. at 627.

88. Id.

89. That is to say, no such evidence is referred to in the judgment.

90. See supra, p. 175. 
sizeable reluctance on the part of the latter to substitute its opinion for that of the doctor". ${ }^{91}$ This statement is question-begging, as the whole point to be decided is what is "negligence in word" in the circumstances. This necessitates knowing the standard to be applied and whether the medical practitioner was competent in this respect. In other words, did the physician breach the required standard relating to disclosure of information to the patient? Contrary to what seems to be implied by Gould J., the answer to this enquiry in no way depends on how "competent" the physician may be in relation to his other duties. The other disquieting factor about this statement is that it sounds very much as though a subjective standard of disclosure from the point of view of the doctor would be accepted and applied by the court.

Such subjective standard-setting, together with the broad view taken of the doctrine of "therapeutic privilege" (by treating it as a matter falling within the notion of the practice of medicine and hence the doctor's general clinical judgment, rather than as an exception to obtaining the informed consent of the patient), plus the criteria on which such therapeutic privilege may be allowed to operate (frightening the patient or causing him to refuse treatment), would give an almost unlimited scope to the doctor's discretion in deciding what should be disclosed.

Another criticism of this approach is that distinguishing "mere communications" and "communications" would be difficult. One wonders, moreover, whether such characterization would also be carried out by expert medical witnesses. If it were, the breadth of the discretion being given to the medical profession to set their own standards would again be increased.

While it is true that the physician-patient relationship itself has a placebo effect, the value of which must be recognized, ${ }^{92}$ one must sometimes sacrifice part of this effect in order to respect the patient's right to autonomy and self-determination. It is a matter of balance as there is no single ultimate good, and in pursuing any one goal others will be adversely affected. Thus the Supreme Court of Canada's approach of a basic policy of adequate disclosure of risks, founded on at least an objective standard of what the reasonable patient would want to know in the circumstances, tempered by a fairly strictly defined "therapeutic privilege", is as near as one can come to the best of all worlds in this respect and is to be welcomed.

Finally, depending upon how it was meant to be interpreted, the final reason given by the Trial Judge for not requiring disclosure to the patient may be somewhat disturbing. In deciding whether a warning of the risk of paralysis should have been given, Gould J. stated: "I think that a legal requirement for such a warning would deter the effective practice of progressive medicine. I hold that the warning given by Dr. Goff was in law adequate." [Emphasis added] ${ }^{93}$ It is not clear exactly what was meant, but to the extent that it is relevant, it should be stated that it is not the function of the court to ensure progress in medicine. Rather, if persons are altruistic enough to volunteer themselves for this purpose knowing the

91. Supra n. 1 at 627.

92. See H.K. Beecher, "Surgery as Placebo", J.A.M.A. 1961, 176: 1102.

93. Supra n. 1 at 627. 
risks, it is a gift and benefit which they freely bestow on the community, even though they may also hope for benefit to themselves. On the other hand, it is the function of the court to protect individual rights and to ensure that persons are not used, more or less as objects, ${ }^{94}$ for purposes to which they have not consented. It is by formulating and applying a doctrine of informed consent of adequate protective content as far as the patient is concerned, that courts may ensure that this does not happen.

It is one question to ask whether, having taken account of both the probability of an undisclosed risk occurring and its seriousness if it did occur, the doctrine of informed consent would require its disclosure. But it is an entirely different matter to accept promotion of the "practice of progressive medicine" as adequate justification for any non-disclosure of risk to the patient. To the extent that any such justification supports an overriding value of medical progress, it makes patients the necessary materials for such progress rather than the purpose of medical progress being to benefit them. The former belief, at the least, fosters an undesirable attitude in the medical profession in particular, and in the community in general.

In the result, the Trial Judge dismissed the plaintiff's action, but appealed to the defendant doctors' charity, in that although "in law [they] are entitled to one set of costs, [w]hen they consider what has befallen their patient, they may well have second thoughts about collecting costs". .5

\section{The Court of Appeal's Judgment}

The Court of Appeal's holding that there was sufficient consent present to negate a cause of action in battery has already been discussed..$^{96}$

But how did the Court of Appeal deal with the allegation of the physician's negligence in failing to obtain "informed" consent? As already noted in discussing the "malpractice in performance" aspects of the case ${ }^{97}$ the Court of Appeal seemed to examine, at the same time, the content of the duty to warn of a certain risk and the duty not to create that risk. The two are not identical. Where the duty is one to warn, the physician fulfills the legal standard of care by giving the required warning and then obtaining the patient's consent. The duty to avoid a certain risk relates to negligence liability with respect to whether the procedure should have been undertaken at all, or how it was carried out. The Court of Appeal found that there was no negligence in these latter respects, ${ }^{98}$ but held, speaking through Carrothers J.A., that "[h]ad the specific risk of paralysis, such as occurred here, been known to radiologists at that time, I would expect the duty of the radiologist would be, not simply to warn the patient of it, but to avoid the very danger itself". ${ }^{99}$ Carrothers J.A. then continued: "In these circumstances of a general unawareness of this

94. See H. Jonas, "Philosophical Reflections on Experimenting with Human Subjects" in Experimentation with Human Subjects (1970, P. Freund ed., George Brazilier, New York) 1 at 3.

95. Supra n. 1 at 626.

96. See supra pp. 180-181.

97. See supra, p. 173.

98. See supra, p. 173-174.

99. Supra n. 2 at 337. 
specific danger at that time in the medical profession, I cannot apply the tests of foreseeability and avoidability urged on us by the appellant and drawn from Wagon Mound Number 2, [1967] 1 A.C. 617." 100

With all respect, this latter statement is confusing. In making it, was the Court referring to the physician's failure to warn the patient, or to his duty not to submit the patient to unreasonable risks of harm, or even to both obligations? In the context, it would appear that the Court was speaking of the physician's obligation of disclosure. If this is correct, then the Court of Appeal was saying either that the physician had no duty to disclose that particular risk, or, that even if the radiologist had breached his duty of disclosure (which they found he had not), there would have been no causation as the damage to the plaintiff would have been, in law, too remote.

Although a court's choice of limiting liability in negligence either via the mechanism of holding that there was no duty or via that of finding no causation, often leads to the same result, that may not be so here. If there was no duty to disclose the risk which crystallized, that is the end of the matter as far as the plaintiff's claim for non-disclosure of that risk is concerned. But if the Court is indicating that even if the plaintiff had been owed a duty of disclosure of that type of risk (i.e., of the risk of paralysis) he would have failed, in the circumstances, to prove causation of the damage by the non-disclosure of any such risk, then the case raises an important point. The issue is the following: the radiologist failed to disclose any risk of paralysis, although there was such a risk known to exist in all angiograms; therefore, would the fact that the risk which eventuated was a "specific risk of paralysis" [emphasis added] ${ }^{101}$ from a source of which the physician was justifiably unaware, excuse him from liability if there had been a breach of a duty to disclose the known risk of paralysis?

A ready answer cannot be given to this question. The test of causation when there has been a negligent non-disclosure of risk by a physician to a patient is whether a reasonable person in the patient's particular circumstances ${ }^{102}$ would have refused the procedure if all the risks, which there was a duty to disclose, had been disclosed. When the risk which should have been disclosed (but was not) is the one which eventuates, the application of the test is straightforward even if the decision as to what the reasonable patient would have decided may not be. But what is the situation where risk $A$, which was disclosed, eventuates, but risk $B$, which was not disclosed but should have been, would have caused the patient to refuse the procedure and hence avoid risk $A$ ? There are two ways of viewing this situation. It is possible to regard the patient's consent as compartmentalized and to argue that he consented to running risk $A$ and hence has no claim arising from its crystallization. Alternatively, one can argue he was only subject to risk $A$ because of a breach of duty of the physician in not disclosing risk $B$, and "but for" this breach, risk $A$ could not have eventuated. Another way of reaching the same result is to argue that the patient's damage is the loss of a chance to avoid running risk $A$, which he would and should have had by risk $B$ being disclosed to him. Although the

100. Id.

101. Id

102. See Reibl v. Hughes, cited supra n. 4 at 14-18, especially 18 and 42-43. 
Supreme Court of Canada does not expressly consider this issue, the general tone of its judgment in Reibl v. Hughes ${ }^{102 a}$ seems to support the latter approach.

However, as outlined, the situation in McLean v. Weir was even more complex. The risk of paralysis which eventuated arose from an unforeseeable source, but the angiogram involved the same type of risk from other foreseeable sources. Assuming that there had been a breach of a duty to disclose the risk of paralysis from the foreseeable sources, could the patient in McLean v. Weir have recovered damages for paralysis resulting from the unforeseeable source? The Court of Appeal was not called upon to deal with this issue because they found no duty to disclose any risk of paralysis. But there may be an indication in the judgment that, even if the known risk of paralysis should have been disclosed and was not, there would have been no liability arising from the crystallization of this unknown "specific risk of paralysis". ${ }^{103}$ That is, total non-disclosure of the risk of paralysis, even in circumstances where the patient should have been informed of some risk of paralysis, possibly would not have been seen by the Court as causally linked to any paralysis which resulted from the unknown risk.

This line of reasoning should be compared with that in cases such as Hughes v. Lord Advocate, ${ }^{104}$ and Chapman v. Hearse. ${ }^{105}$ There the courts held that a positive finding of causation-in-law depended on reasonable foreseeability of the general way in which the reasonably foreseeable type of damage was caused, rather than the specific details of the chain of events. Thus, the breadth of the terms used to describe the way in which a particular damaging event occurred will determine whether or not there was the reasonable foreseeability required for causation-in-law, when the resulting damage is itself of a type which was reasonably foreseeable. The more general the description the more easily causation-in-law will be found to be present. For instance, in McLean v. Weir, if the known risk of paralysis should have been disclosed but was not, and the unknown risk of paralysis eventuated, there are two alternative ways to formulate the test of whether the non-disclosure is the cause-in-law of the resulting damage. Depending upon which formula is chosen, there will be either a positive or negative finding of causation-in-law. First, the damaging event, which must be reasonably foreseen for there to be causation-inlaw, can be described as "an angiogram giving rise to paralysis". In this case there will be reasonable foreseeability of the damage occurring in the way described (that is, by way of an angiogram, even though it arose from an unexpected sequence of events). Hence there will be causation-inlaw. In contrast, if the damaging event is described as "an angiogram in which the cause of the paralysis was a previously unknown source" there

102a. Id.

103. Supra n. 2 at 337.

104. [1963] A.C. 837.

105. (1961) 106 C.L.R. 112. 
is no such reasonable foreseeability, and causation is not established. ${ }^{106}$

\section{CONCLUSION}

Although the legal issues are complex, the problems raised by McLean v. Weir are fundamental. They exist at the level of the policy value choice made in relation to support for individual rights, in particular the individual's right of self-determination or autonomy.

The Trial Court made its choice through the mechanism of directly adopting expert medical evidence as setting the required legal standard of care, and the Court of Appeal supported the result. This should be compared with the possible alternative approach in which $a$ court sets the legal standard on the basis of expert medical evidence. It is this alternative which has now been adopted by the Supreme Court of Canada. ${ }^{107} \mathrm{To}$ the extent that the Supreme Court's approach represents a change in the law it is to be welcomed, as the use of expert medical evidence to directly set a legal standard contrasts with the approach of courts in other jurisdictions, ${ }^{108}$ and in other areas of law, and even with the way in which legal standards required of physicians in carrying out medical practices ${ }^{109}$ (with the exception of obtaining consent) are set. Although there may

106. The difference between these types of description can be seen by comparing Hughes $\mathrm{v}$. Lord Advocate (supra n. 104) and Doughty v. Turner Manufacturing Co. [1964] 1 Q.B. 518. In the former case the Court held that the source of the damage (a burning paraffin lamp) was known and the risk of damage by burning was reasonably foreseeable. Hence, even though the exact chain of events (the lamp causing an explosion, knocking the plaintiff down an open man-hole, as a result of which he was severely burnt) was not specifically foreseeable, causation-in-law was found to be present. Similarly, in McLean v. Weir, assuming for the purposes of discussion that the type of damage, a risk of paralysis, was reasonably foreseeable, one could say that the source of the damage, the angiogram procedure, was known. It was just that the exact way in which this reasonably foreseeable damage occurred was not anticipated. But, by analogy to Hughes v.Lord Advocate, this will not negate a positive finding of causation-in-law.

In comparison, in Doughty v. Turner Manufacturing Co. the plaintiff was burnt by an extremely hot cyanide solution, which erupted due to a chemical reaction when an asbestos cover slid into the vat in which it was contained. The Court rejected an argument that damage in the nature of burning caused by splashing if the cover were negligently allowed to fall in, was reasonably foreseeable and, therefore, the events which occurred were simply a variation of this fact pattern and were also sufficiently reasonably foreseeable for causation-in-law. The Court held, rather, that the damage was caused by an unforeseeable source - the chemical reaction - and hence there was no causation-in-law. Similarly, in McLean v. Weir, if the unknown risk of paralysis is held to be a separate and unforeseeable source of damage (although that damage is of the same type as could arise from a foreseeable source) there will be no causation-in-law.

It is suggested that depending upon whether a court chooses an outcome of liability to compensate or not, it will accordingly choose one or other of the above analyses. If the court focuses on the nature of the damage as being similar in the foreseeable instance and in the variation of that reasonably foreseeable fact pattern which is under scrutiny, this will lead to a conclusion that causation-in-law is present, as in Hughes v. Lord Ad. vocate. On the other hand, if the Court focuses on the dissimilarity of the chain of events, or of the source of the damage in the two instances which are being compared, only one of which clearly fulfils the criteria for reasonable foreseeability, this will justify distinguishing the two instances as far as a finding of reasonable foreseeability and hence causation-in-law is concerned.

107. See Reibl v. Hughes, supra n. 4.

108. See for example, in the United States, Cobbs v. Grant 502 P. 2d 1 (1972); Canterbury v. Spence supra n. 37.

109. See, for example, Villemure v. Turcot [1973] S.C.R. 716; Anderson v, Chasney [1949] 4 D.L.R. 71, affd. [1950] 4 D.L.R. 223 (S.C.C.); Crits v. Sylvester [1955] 3 D.L.R. 181 (Ont. H.C.); Helling v. Carey, supra n. 24. 
seem to be only a subtle or theoretical variation in nuance between these two approaches, that variation can be manifested as significantly different practical realities which affect every physician-patient relationship and not just the minuscule percentage which culminate in litigation.

Further, the actual content of the expert medical evidence adopted by the Courts in McLean v. Weir unfortunately espouses a view which tends to deny the individual nature of the physician-patient relationship and the personal rights therein, especially the patient's right to autonomy. This is not to say that the particular result reached in the case is insupportable. Rather, it is the manner in which that result is sometimes supported and the precedent-setting effect of such reasoning which are not acceptable. As medical evidence on the custom of the medical profession in disclosing risks to patients is still relevant to determining which medical risks must be disclosed, the fact that this evidence was used to set the required standard of disclosure is still important as far as precedent is concerned. In this respect, it is to be hoped that the spirit of the Supreme Court of Canada's decisions will have a tempering effect.

The medical relationship is one of the most delicate and, hopefully, human of human encounters and there is sometimes great difficulty in balancing the competing values involved. This balancing is never simple when the choice, as it often is in this relationship, is between "good and good" rather than "good and evil". However, there has been a marked move away from paternalism in medicine, accompanied by an increased consumerism on the part of patients. The development of the doctrine of informed consent displays both of these trends. Some may regard such moves as highly regrettable, others as commendable. As with most changes, there is truth in both views. But the reality is that most contemporary patients want at least to be offered the chance to accept or reject the opportunity to choose which risks they will run. It is only by developing a legally vigorous but humane doctrine of informed consent that such opportunity, and with it a thorough-going right to self-determination in the medical relationship, may be established in the law of each of the provinces of Canada. In this respect, McLean $\mathrm{v}$. Weir is one example of the old order which was changed to give place to the new in Reibl v. Hughes. 